\title{
Occurrence, Virulence, Inoculum Density and Plant Age of Sclerotium rolfsii Sacc. Causing Collar Rot of Peppermint
}

Arjunan Muthukumar* and Arjunan Venkatesh

Department of Pant Pathology, Faculty of Agriculture, Annamalai University, Annamalainagar, Chidambaram, Tamil Nadu, India

\begin{abstract}
Roving survey was conducted during 2011-2012 around Coimbatore, Dindigul, Erode, Hosur, Krishnagiri, Namakkal, Salem and Theni districts to assess the incidence of collar rot of peppermint. The maximum incidence of $32.33 \%$ was recorded in Therkupalayam village of Coimbatore District. The pathogen was isolated from infected samples and 8 Sclerotium rolfsii isolates were maintained. The level of pathogenicity of these isolates revealed that $S$. rolfsii $\left(\mathrm{I}_{1}\right)$ from Therkupalayam in Coimbatore District was the most virulent and caused higher levels of collar rot incidence (93.66\%). An inoculum load of S. rolfsii at $5 \%$ to $1 \mathrm{~kg}$ of soil registered the maximum incidence of $92.66 \%$ collar rot of peppermint. Significantly higher per cent of wilting of $92.66 \%$ was recorded in plants at 20 days after emergence and it was found significantly more susceptible compared to rest of the treatments.
\end{abstract}

Keywords: Peppermint; Sclerotium rolfsii; Survey; Pathogenicity; Inoculum levels

\section{Introduction}

Mentha piperita L. is an important aromatic perennial herb grown throughout the world, belonging to the family Lamiaceae. It is extensively cultivated in India and about $70 \%$ of the International annual requirement is met from crops raised in the central region of the Indo-Gangetic plains [1]. Mentha is cultivated in Himalaya-hills, Haryana, Uttar Pradesh, Punjab and Bihar. Of these, Uttar Pradesh is the largest producing state in the country contributing $80-90 \%$ of the total production followed by Punjab, Haryana, Bihar and Himachal Pradesh. Peppermint oil is used to cure indigestion, headaches, colic, gingivitis, irritable bowel syndrome, spasms and rheumatism. It is also used in the manufacture of mint sweets and chocolates. In India, peppermint is grown throughout the year [2] and it is affected by several fungal diseases caused by Rhizoctonia solani [3], Verticillium dahliae [4], Collectotrichum cocodes [5], R. solani [6] and Sclerotium rolfsii [7]. Of these, collar rot caused by Sclerotium rolfsii is a major constraint in the peppermint cultivation in Tamil Nadu. It is a soil borne plant pathogen which causes considerable damage to the crop and the disease intensity in the field ranged from 5 to $20 \%$ [7]. The objectives of the present study are i) to survey on the incidence of collar rot of peppermint from Tamil Nadu, ii) to assess the virulence of $S$. rolfsii isolates iii) to know the susceptible stage of crop to collar rot of peppermint.

\section{Materials and Methods}

\section{Survey on the incidence of collar rot of mint in different districts of Tamil Nadu}

Surveys were carried out in important mint growing tracts viz., Coimbatore, Dindigul, Erode, Hosur, Krishnagiri, Namakkal, Salem and Theni districts of Tamil Nadu to assess the severity of collar rot incidence. At each place, three fields were selected. Five plots $\left(1 \mathrm{~m}^{2}\right)$ were selected randomly in each field and 100 plants in each plot were selected randomly. Observations were recorded and per cent disease incidence was calculated using the following formula.

$$
\text { Per cent disease incidence }=\frac{\text { Number of plants infected }}{\text { Total number of plants observed }} \times 100
$$

\section{Isolation and maintenance of pathogen}

The collar rot symptoms were collected from major mint growing tracts of Tamil Nadu pertaining to districts such as Coimbatore, Dindigul, Erode, Hosur, Krishnagiri, Namakkal, Salem and Theni. The infected plant materials brought back from the field were washed, cut into $5 \mathrm{~mm}$ segments including the advancing margins of infection. The segments were surface sterilized in $0.5 \%$ sodium hypochlorite solution for $5 \mathrm{~min}$. and rinsed in three changes of sterile distilled water. The segments were separately dried in between sheets of sterile filter paper and placed ( 3 pieces per plate) on fresh potato dextrose agar (PDA) medium [8] impregnated with streptomycin, and incubated for seven days at $28 \pm 2^{\circ} \mathrm{C}$.

A total of eight isolates $\left(\mathrm{I}_{1}\right.$ to $\left.\mathrm{I}_{8}\right)$ causing collar rot was isolated from infected plant samples collected from different tracts of Tamil Nadu. The fungal growth on $5^{\text {th }}$ day, which arose through the sclerotial bodies was cut by inoculation loop and transferred aseptically to the PDA slants and allowed to grow at room $\left(28 \pm 2^{\circ} \mathrm{C}\right)$ temperature to obtain the pure culture of the fungus. The culture thus obtained was stored in refrigerator at $5^{\circ} \mathrm{C}$ for further studies and was sub cultured periodically. The purified isolates were identified based on morphological and colony characteristics [9-11]. They were identified as Sclerotium rolfsii (Plates 1-3).

\section{Mass multiplication of $S$. rolfsii isolates}

A total of eight isolates were multiplied in sand corn-meal medium [12]. Two hundred grams of sand corn meal mixture was taken in 500 $\mathrm{mL}$ conical flasks and mixed with $30 \%$ of distilled water and they were sterilized at $15 \mathrm{lb}$ pressure for $20 \mathrm{~min}$. The pure culture of each isolate of $S$. rolfsii was inoculated to these flasks under aseptic conditions and incubated at $28 \pm 2^{\circ} \mathrm{C}$ for 20 days. These flasks were shaken periodically

*Corresponding author: Arjunan Muthukumar, Department of Plant Pathology, Faculty of Agriculture, Annamalai University, Chidambaram, Tamil Nadu, India, Tel: 09443129959; E-mail: muthu78ap@yahoo.co.in

Received: November 08, 2013; Accepted December 05, 2013; Published December 09, 2013

Citation: Muthukumar A, Venkatesh A (2013) Occurrence, Virulence, Inoculum Density and Plant Age of Sclerotium rolfsii Sacc. Causing Collar Rot of Peppermint. J Plant Pathol Microb 4: 211. doi:10.4172/2157-7471.1000211

Copyright: ( 2013 Muthukumar A, et al. This is an open-access article distributed under the terms of the Creative Commons Attribution License, which permits unrestricted use, distribution, and reproduction in any medium, provided the original author and source are credited. 
Citation: Muthukumar A, Venkatesh A (2013) Occurrence, Virulence, Inoculum Density and Plant Age of Sclerotium rolfsii Sacc. Causing Collar Rot of Peppermint. J Plant Pathol Microb 4: 211. doi:10.4172/2157-7471.1000211

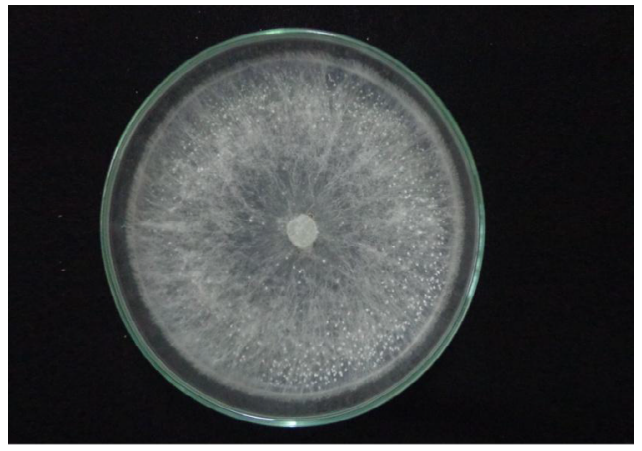

Plate 1: Axenic culture of Sclerotium rolfsii.

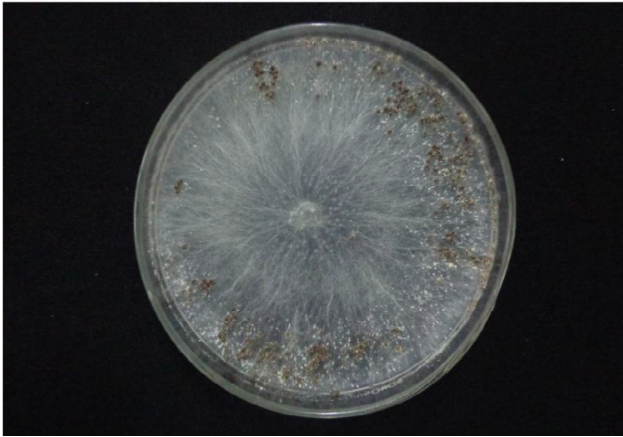

Plate 1: Sclerotial formation of S. rolfsii.

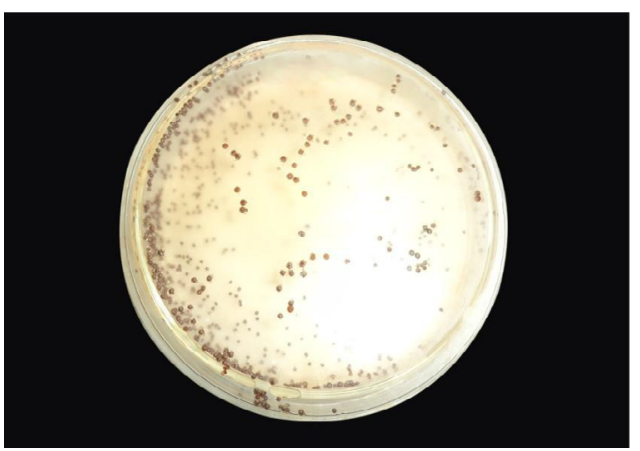

Plate 3: Mustard like brown colour sclerotia

to get uniform growth of the pathogen. The mass cultures thus obtained were used for further studies.

\section{Assessing the virulence of $S$. rolfsii isolates}

The pot mixture was prepared by thoroughly mixing clay loam soil, sand and farm yard manure at the ratio of 1:1:1. The inoculum of each isolate of $S$. rolfsii grown on sand-corn meal medium (twenty days old) was mixed thoroughly at 5\% (w/w basis) level, and applied to top two centimeter of the soil. Then apparently healthy surface sterilized mint cuttings were planted in inoculated pots. The cuttings planted in pots without inoculum served as control. Soil moisture was maintained at moisture holding capacity of soil by adding sterilized water on weight basis throughout the period. After, 20 days of inoculation, the plants showing the typical wilting symptoms were observed. Re isolation was made from such affected portion of the plant tissue and compared with that of original isolate for conformity.
Effect of different levels of inoculum of $S$. rolfsii $\left(I_{1}\right)$ on the incidence of collar rot of mint

The soil, sand and farmyard manure were sieved by passing through $2 \mathrm{~mm}$ mesh and sterilized separately and then mixed in 1:1:1 per cent proportion, respectively. After mixing, it is filled in $15 \times 30$ $\mathrm{cm}$ surface sterilized earthen pots. S. rolfsii culture grown on sandcorn meal medium for 20 days was mixed to each pot so as to give different inoculum levels viz., 0, 1, 2, 3, 4 and 5\%. The pots filled with sterilized soil without inoculum served as control (un-inoculated). Each treatment was replicated three times. Apparently healthy cuttings of mint (8/pot) were planted in pots. Water was added to the pots at regular intervals to maintain the soil moisture. The observation on the incidence of collar rot was recorded.

\section{Identification of susceptible stage of the crop to collar rot of mint}

To know the susceptible stage of the crop, an experiment was conducted under glasshouse condition. Five stages of the mint crop were taken for their susceptible reaction with the collar rot causal pathogen $S$. rolfsii. These stages of crop were maintained in the earthen pots of $15 \times 30 \mathrm{~cm}$ diameter filled with sterilized soil. After raising all the stages, the inoculum was added at $5 \%$ level. After 20 days, number of plants showing wilting symptom due to $S$. rolfsii was recorded (Table 1).

\section{Results}

\section{Survey of collar rot incidence of mint in Tamil Nadu}

Roving survey was conducted during 2011-2012 around Coimbatore, Dindigul, Erode, Hosur, Krishnagiri, Namakkal, Salem and Theni districts to assess the incidence of collar rot of mint and the data are presented in the Table 2 . The symptoms in the field were recognized by wilting and drying of the entire plant. Upon close observations on such affected plant revealed the presence of white cottony mycelium at the collar region, dark brown coloured mustard like sclerotial bodies were found adhering on the mycelial growth of the affected stem and at collar region (Plates 4 and 5).

The incidence of collar rot from different districts of Tamil Nadu

\begin{tabular}{|c|c|c|}
\hline Treatments & Stage & Days after emergence \\
\hline$T_{1}$ & $1^{\text {st }}$ & Zero stage \\
\hline$T_{2}$ & $2^{\text {nd }}$ & 20 days old crop \\
\hline$T_{3}$ & $3^{\text {rd }}$ & 40 days old crop \\
\hline$T_{4}$ & $4^{\text {th }}$ & 60 days old crop \\
\hline$T_{5}$ & $5^{\text {th }}$ & 80 days old \\
\hline$T_{6}$ & $6^{\text {th }}$ & 100 days old crop \\
\hline
\end{tabular}

Table 1: Treatments of Sclerotium rolfsii at different stages.

\begin{tabular}{|c|c|c|}
\hline Name of the district & Name of the Village & Disease incidence (\%) \\
\hline Coimbatore & Therkupalayam & $32.33 \mathrm{a}^{*}(34.65)$ \\
\hline Erode & Vattur & $18.66 \mathrm{f}(25.60)$ \\
\hline Hosur & Alangudi & $28.66 \mathrm{~b}(32.36)$ \\
\hline Krishnagiri & Pochampalli & $14.00 \mathrm{~g}(21.97)$ \\
\hline Namakkal & Morepalayam & $25.66 \mathrm{c} \mathrm{(30.43)}$ \\
\hline Dindigul & Kattuvalasu & $21.66 \mathrm{~d}(27.73)$ \\
\hline Salem & Edappadi & $20.00 \mathrm{e} \mathrm{(26.56)}$ \\
\hline Theni & Attupalam & $30.33 \mathrm{a} \mathrm{(33.41)}$ \\
\hline
\end{tabular}

*Values in each column followed by the same letter are not significantly different according to the DMRT method $(P=0.05)$.

Table 2: Survey of collar rot of mint in Tamil Nadu. 
Citation: Muthukumar A, Venkatesh A (2013) Occurrence, Virulence, Inoculum Density and Plant Age of Sclerotium rolfsii Sacc. Causing Collar Rot of Peppermint. J Plant Pathol Microb 4: 211. doi:10.4172/2157-7471.1000211

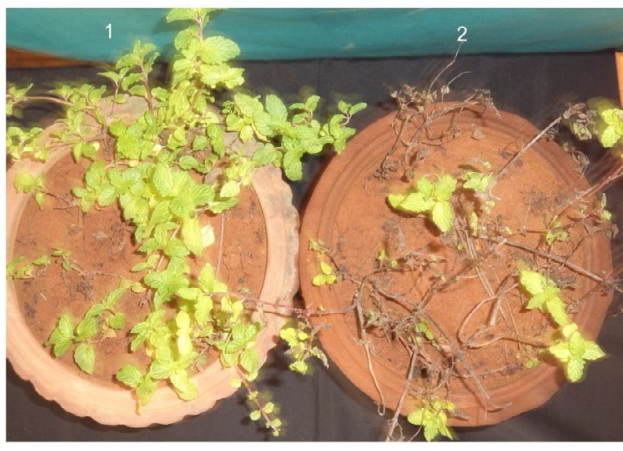

Plate 4: Symptoms of collar rot of mint.

I. Healthy

2. Infected

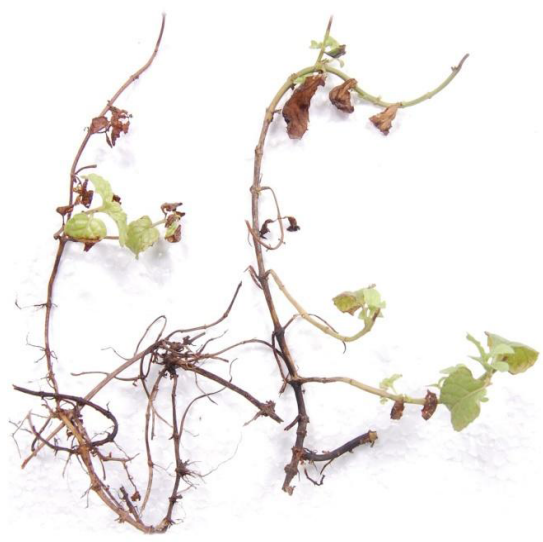

Plate 5: A view of infected and Healthy Seedlings.

ranged from 14.00 to $32.33 \%$. The maximum incidence of $32.33 \%$ was recorded in Therkupalayam village of Coimbatore District. This was followed by Attupalam village of Theni district (30.33\%). Whereas, least disease incidence of $14.00 \%$ was recorded in Pochampalli village of Krishnagiri district.

\section{Pathogenicity of $S$. rolfsii isolates on mint}

The data presented in Table 3 revealed that the level of pathogenicity varied between the isolates. Among the 8 isolates of $S$. rolfsii, the isolate- $\mathrm{I}_{1}$ (Therkupalayam) recorded the maximum disease incidence of 93.66\%. It was followed by the isolate- $\mathrm{I}_{8}$ and $\mathrm{I}_{3}$ collected from Attupalam and Alangudi which were found to differ significantly from isolate- $\mathrm{I}_{1}$. The isolate- $\mathrm{I}_{4}$ (Pochampalli) recorded the least incidence of collar rot recording $56.66 \%$. The isolate- $\mathrm{I}_{1}$ was found to be more virulent when compared to other isolates tested in the present study. Hence, the isolate- $\mathrm{I}_{1}$ alone was taken for the subsequent experiments.

\section{Effect of different inoculum levels on the incidence of collar rot of mint}

Among the various inoculum levels tested, 5\% inoculum load of $S$. rolfsii to $1 \mathrm{~kg}$ of soil registered the maximum incidence of $92.66 \%$ collar rot which was followed by the $4 \%$ inoculum load of S. rolfsii. Ultimately the results emphasized that the disease incidence increased with the increase in the inoculum load up to $5 \%$ beyond which the disease incidence was found to decline (Table 4).

\section{Identification of susceptible stage of the crop}

To find out the susceptible stage of the crop to collar rot disease, an experiment was laid out in glasshouse conditions as explained in materials and methods. The results are presented in the Table 5. The results revealed that, there was significant difference in wilting percentage among the different stages of the plants. Significantly higher per cent of wilting of $92.66 \%$ was recorded in plants at 20 days after emergence and it was found significantly more susceptible compared to rest of the treatments. Stage of 60 and 80 days old plants recorded 29.00 and $14.66 \%$ incidence, respectively. Whereas, the least wilted plants were observed in age group of 120 days old plants.

\section{Discussion}

A roving survey was carried out in different districts of Tamil Nadu viz., Coimbatore, Dindigul, Erode, Hosur, Krishnagiri, Namakkal, Salem and Theni during 2011-2012. The data on survey revealed that the incidence of collar rot of mint varied from locality to locality, because of varied agro climatological situations, cropping patterns and also cultural practices followed. Even, it could also be attributed to the existence of variability (or) pathogenic diversity present in the fungus. The similar observation was made on the incidence of sclerotium wilt of potato caused by $S$. rolfsii at different localities of Belgaum and Dharwad districts [13].

Survey on the incidence of collar rot from different districts of

\begin{tabular}{|c|c|}
\hline Isolate number & Disease incidence (\%) \\
\hline $\mathrm{I}_{1}$ & $93.66 \mathrm{a}^{*}(75.42)$ \\
\hline $\mathrm{I}_{2}$ & $52.00 \mathrm{~h}(46.14)$ \\
\hline $\mathrm{I}_{3}$ & $63.00 \mathrm{c}(64.90)$ \\
\hline $\mathrm{I}_{4}$ & $56.66 \mathrm{~g}(48.82)$ \\
\hline $\mathrm{I}_{5}$ & $82.00 \mathrm{f}(52.53)$ \\
\hline $\mathrm{I}_{6}$ & $75.33 \mathrm{~d}(60.21)$ \\
\hline $\mathrm{I}_{7}$ & $70.66 \mathrm{e}(57.20)$ \\
\hline $\mathrm{I}_{8}$ & $89.33 \mathrm{~b}(70.93)$ \\
\hline Control & $0.00 \mathrm{i}(0.00)$ \\
\hline
\end{tabular}

*Values in each column followed by the same letter are not significantly different according to the DMRT method $(P=0.05)$.

Table 3: Pathogenicity of $\mathrm{S}$. rolfsii isolates on mint.

\begin{tabular}{|c|c|}
\hline Inoculum level (\%) & Disease incidence (\%) \\
\hline 0 & $0.00 \mathrm{f}^{*}(0.00)$ \\
\hline 1 & $18.66 \mathrm{e}(25.59)$ \\
\hline 2 & $26.00 \mathrm{~d}(30.65)$ \\
\hline 3 & $48.00 \mathrm{c}(43.85)$ \\
\hline 4 & $79.33 \mathrm{~b}(62.97)$ \\
\hline 5 & $92.66 \mathrm{a}(74.29)$ \\
\hline
\end{tabular}

*Values in each column followed by the same letter are not significantly different according to the DMRT method $(P=0.05)$.

Table 4: Effect of different inoculum levels on the incidence of collar rot of mint.

\begin{tabular}{|c|c|}
\hline Treatments & Disease incidence (\%) \\
\hline T1-Zero stage & $0.00 \mathrm{f}^{*}(0.00)$ \\
\hline T2-20 days old crop & $92.66 \mathrm{a}(74.28)$ \\
\hline T3-40 days old crop & $60.33 \mathrm{~b}(50.96)$ \\
\hline T4-60 days old crop & $29.00 \mathrm{c}(32.58)$ \\
\hline T5-80 days old & $14.66 \mathrm{~d}(22.50)$ \\
\hline T6-100 days old crop & $8.33 \mathrm{e} \mathrm{(16.77)}$ \\
\hline
\end{tabular}

*Values in each column followed by the same letter are not significantly different according to the DMRT method $(P=0.05)$.

Table 5: Identification of susceptible stage of the crop. 
Tamil Nadu ranged from 14.00 to $33.00 \%$. The maximum incidence of $32.33 \%$ was recorded in Therkupalayam village of Coimbatore district. This was followed by Attupalam village of Theni district (30.33\%). However, the disease incidence was relatively less in Pochampalli village of Krishnagiri district (14.00\%). The higher incidence of collar rot in Therkupalayam village may be due to continuous cropping and presence of pathogen over long period, because continuous cultivation of any crop over the season and years will build up inoculum level to such an extent as observed by various workers [14-16].

Pathogenicity test was carried out under pot culture conditions in glass house by inoculating with pathogenic culture of $S$. rolfsii. Among the isolates tested, $S$. rolfsii isolated $\left(\mathrm{I}_{1}\right)$ from Therkupalayam area pertaining to Coimbatore district was found to be highly virulent in causing collar rot compared to other isolates investigated in the present study. This was followed by isolate $\left(\mathrm{I}_{8}\right)$ from Attupalam area pertaining to Theni district. Earlies studies proved the pathogenicity of $S$. rolfsii on cardamom in pot culture studies by inoculating 25 days old sclerotial cultures which was grown on sand corn meal medium and observed the symptoms a week after inoculation [17]. Similarly, variation in the virulence of the isolates of $S$. rolfsii causing collar rots of chilli, potato and soybean has been reported by several workers $[16,18,19]$. Present study also corroborate with the findings of above researchers explaining that the isolate of $S$. rolfsii $\left(\mathrm{I}_{1}\right)$ is highly virulent in causing collar rot disease.

In the present study, it was observed that $S$. rolfsii can infect all the stages of the mint crop, when inoculum was added to all the stages. But the susceptible stage of the crop can be identified based on the stage at which the crop shows the maximum symptoms of collar rot caused by S. rolfsii. It was found that, after 20 days of inoculation $\left(\mathrm{T}_{2}-20\right.$ days after emergence stage) mint crop showed maximum mortality $(92.66 \%)$ and it was identified as the most susceptible stage. Similarly, chilli seedlings were found most susceptible to the attack of $S$. rolfsii during first thirty days of the growth and the per cent infection of the plant reduced with ageing [20]. Barley seedlings were found most susceptible to the attack of $S$. rolfsii during first fifteen days of the growth and the per cent infection of the plant reduced with ageing [21]. The most susceptible growth stage of groundnut $S$. rolfsii infection was at 15 days old plant and the least mortality in 105 days old plants [3]. The above results lend support to the present findings.

Among the inoculum levels tested, 5\% inoculum load of S. rolfsii registered the maximum incidence of collar rot, which was followed by $4 \%$ inoculum level. Similarly, Sclerotium wilt of potato where the incidence increased with the increase in concentration of inoculum upto $4 \%$ [22]. Higher inoculum density resulted in highest disease incidence, which may be due to the fact that higher inoculum always ensures the certainty of the infection. Similar results have been reported by several workers [23-25].

\section{References}

1. Singh AK, Srivastava RK, Kumar S (1999) Production and trade of menthol mint in India. Curr Sci 87.

2. Shukla PK, Haseeb AS, Sharma S (1998) Soil texture, root lesion nematodes and yield of peppermint (Mentha piperita). J Herbs Spices Med Plants 6: 1-8.

3. Kumar S, Khol AP, Pata DD, Rar TM, Sinqii S, Tyagi BR (1997) Cultivation of menthol mint in India. Farm Bulletin 4: 13-20.

4. Johnson DA, Santo GS (2001) Development of wilt in mint in response to infection by two pathotypes of Verticillium dahliae and co infection by Prataylenchus penetrans. PI Dis 85: 1189-1192.

5. Johnson DA, Douhan LI, Greary B (2002) Report of Colletotrichum cocodes associated with mentha. PI Dis 86: 695.
6. Merin Babu (2002) Studies on epidemiological and stolon rot of mentha. Thesis, Department of Plant pathology, Tamil Nadu Agricultural University, Coimbatore, Tamil Nadu, India.

7. Anand S, Harikesh Bahadur S (2004) Control of collar rot in mint (Mentha spp.) caused by Sclerotium rolfsii using biological means. Curr Sci 87: 362-366.

8. Ainsworth GC (1961) Dictionary of fungi. Common Wealth Mycological Institute, Kew Burrey, England 547.

9. Punja ZK, Damiani A (1996) Comparative growth, morphology and physiology of three Sclerotium species. Mycologia 88: 694-706.

10. Sarma BK, Singh UP, Singh KP (2002) Variability in Indian isolates of Sclerotium rolfsii. Mycologia 94: 1051-1058.

11. Watanabe T (2002) Sclerotium sp. morphologies of cultured fungi and key species: Pictorial Atlas of Soil and Seed fungi. (2ndedn), CRC Press, New York.

12. Abeygunawardena DVW, Wood RKS (1957) Factors affecting the germination of sclerotia and mycelial growth of Sclerotium rolfsii Sacc. Trans British Mycol Soc 40: 221-231.

13. Anahosur KH, Kulkarni S (1997) Survey of potato Sclerotium within parts of Karnataka. Indian Phytopathological Society 18-29.

14. Baswaraj R (2005) Studies on potato wilt caused by Sclerotium rolfsii Sacc Thesis, University of Agricultural Sciences, Dharwad.

15. Kulkarni SA, Kulkarni S, Anahosur KH (1994) Effect of age of groundnut plant to infection of Sclerotium rolfsii Sacc. a causal agent of stem rot disease. Karnataka J Agrl Sci 7: 367-268.

16. Praveen Kumar N (2009) Studies on biological management of collar rot of sesame caused by Sclerotium rolfsii Sacc. Thesis, University of Agricultural Sciences, Dharwad 67.

17. Siddaramaiah AL, Chandrappa HM (1988) New collar rot disease on Desmodium uncinatum and Lutononis bainesii from India. Curr Res 16: 82.

18. Bhuiyan MA, Rahman HB, Bhuiyan KA (2012) In vitro screening of fungicides and antagonists against Sclerotium rolfsii. African $\mathrm{J}$ Biotechnol 11: 1482214827.

19. Jyothi KC (2006) Morphological and molecular variability among the isolates of Sclerotium rolfsii Sacc. from different host plants. Thesis, University of Agricultural Sciences, Dharwad 77.

20. Vinod D (2006) Studies on Root rot of chilli caused by Sclerotium rolfsii Sacc Thesis, University of Agricultural Sciences, Dharwad 55.

21. Singh RK, Dwivedi RS (1988) Effect of age on disease development in barley. National Academy of Science Letters 10: 263-266.

22. Kulkarni VR (2007) Epidemiology and integrated management of potato caused by Sclerotium rolfsii Sacc. [PhD] Thesis, University of Agricultural Sciences, Dharwad.

23. Chitrampalam P, Turin TA, Matheron ME, Pryor BM (2010) Effect of Sclerotium density and irrigation on disease incidence and on efficacy of Coniothyrium minitans in suppressing lettuce crop caused by Sclerotinia sclerotium. Plant Dis 94: 1118-1124.

24. Hussain A, lqbal SM, Ayub N, Zahid MA (2006) Factors affecting development of collar rot disease in chickpea. Pakistan J Bot 38: 211-216.

25. Sennoi R, Jogloy S. Saksirirat W, Kesmala T, Singkhan N, et al. (2012) Levels of Sclerotium rolfsii inoculum influence identification of resistant genotypes in Jerusalam artichoke. J Microbiol Res 6: 6755-6760. 